Sukarni, Djoko Priyono, Mita, Junaidi, Usman, Peningkatan Penyembuhan Luka Kaki Diabetik Neuropati Dengan Menggunakan Off-Loading Sederhana

\title{
PENINGKATAN PENYEMBUHAN LUKA KAKI DIABETIK NEUROPATI DENGAN MENGGUNAKAN OFF-LOADING SEDERHANA
}

\author{
Sukarni ${ }^{1}$ \\ Jurusan Keperawatan Fakultas Kedokteran Universitas Tanjungpura \\ Corresponding author E-mail : sukarni@ners.untan.ac.id \\ Djoko Priyono² \\ Jurusan Keperawatan Fakultas Kedokteran Universitas Tanjungpura \\ Corresponding author E-mail : djoko.priyono@ners.untan.ac.id \\ Mita ${ }^{3}$ \\ Jurusan Keperawatan Fakultas Kedokteran Universitas Tanjungpura \\ Junaidi $^{4}$ \\ Klinik PKU Muhammadiyah Kitamura Pontianak \\ Corresponding author E-mail : jun51495@gmail.com \\ Usman ${ }^{5}$ \\ STIK Muhammadiyah Pontianak \\ Corresponding author E-mail : usmanudan@stikmuhptk.ac.id
}

\begin{abstract}
ABSTRAK
Perawatan luka kaki diabetik neuropati membutuhkan waktu yang lama dalam proses penyembuhannya. Perawatan luka yang telah diberikan kurang maksimal karena area luka selalu mengalami tekanan yang mengakibatkan luka menjadi terhambat untuk perbaikan jaringan. Offloading sederhana merupakan intervensi yang dapat membantu mengurangi tekanan pada area luka. Luka yang tidak terjadi penekanan membantu mempercepat penyembuhan. Tujuan dari penelitian ini adalah untuk mengetahui dan mengevaluasi percepatan penyembuhan pada luka kaki diabetik neuropati dengan menggunakan metode Off-loading sederhana. Jenis penelitian yang digunakan yaitu penelitian eksperimen dengan desain quasi eksperimen. Total sampel 16 sampel tetapi 7 sampel tidak diintervensi karena tidak melakukan kunjungan kembali dan mengalami infeksi berulang. Perawatan luka menggunakan standar perawatan luka Klinik Kitamura yang ditambahkan dengan Off-loading sederhana. Luka dievaluasi setelah 4 minggu pengobatan yang meliputi skor luka (MUNGs) dan ukuran luka. Uji yang digunakan yaitu uji-t berpasangan dan uji Wilcoxon. Hasil Jenis kelamin terbanyak adalah perempuan (88,9\%), tidak merokok $(88,9 \%)$ dan monofilamen sebagian besar tidak normal $(55,6 \%)$. Usia rata-rata adalah 53,56 tahun, rata-rata GDS $255 \mathrm{mg} / \mathrm{dl}$ dan nilai $A B I$ rata-rata 0,95. Uji bivariat Skor luka sebelum dan sesudah intervensi dengan $p=0.05$ dan ukuran luka dengan $p=0.11$. Penggunaan offloading sederhana berpengaruh pada percepatan penyembuhan luka kaki diabetik neuropati.
\end{abstract}

Kata Kunci : Luka Kaki Diabetik Neuropati, Off-loading sederhana, Foam

\section{ABSTRACT}

Treatment of diabetic neuropathy foot ulcers requires a long time in the healing process. Wound care that has been given is not optimal because the area of the wound always experiences pressure resulting in the wound becoming obstructed to repair the tissue. Simple Off-loading becomes an intervention that helps reduce pressure on the injured area. Wounds that do not occur will quickly suppress the healing process. The purpose of this research is to find out and evaluate the acceleration of wound healing in diabetic neuropathy feet using simple Off-loading. The type of research used is experimental research with a quasi-experimental design. The total sample of 16 but 7 samples were not intervened due to not making a return visit and having recurrent infections. Treatment uses the standard Kitamura Clinic wound care which is coupled with simple Off-loading. Wounds were evaluated after 4 weeks of treatment which included wound scores (MUNGs) and wound size. Using a paired t-test and Wilcoxon test. Results The largest sex was female (88.9\%), most did not smoke (88.9\%) and monofilament was mostly abnormal (55.6\%). The mean age was 53.56, the average GDS was 255 and the average branchial Ankle 
Value index was 0.95. Bivariate test Wound scores before and after intervention with $p=0.05$ and wound size with $p=0.11$. The use of simple Off-loading affects accelerating the healing of diabetic foot ulcers in neuropathy.

\section{Keywords : Diabetic Foot Ulcers Neuropathy, Simple Off-loading, Foam}

\section{PENDAHULUAN}

Jumlah penderita DM didunia terus terjadi peningkatan, pada tahun 2010-2030 yaitu sebesar $54 \%$ dengan prevalensi terbesar di sepuluh negara antara lain India 50,8 juta, China 43,2 juta, Amerika serikat 26,8 juta, Rusia 9,6 juta, Brazil 7,6 juta, Jerman 7,5 juta, Pakistan 7,1 juta, Jepang 7,1 juta, Indonesia 7,0 juta dan Meksiko 6,8 juta (Shaw et al., 2010). Indonesia terus mengalami peningkatan jumlah penderita DM dengan nilai dari $6,9 \%$ menjadi $8,5 \%$ (Riskesdas, 2018). Jumlah kasus Diabetes di Provinsi Kalimantan Barat menempati peringkat ke-4 dari 10 penyakit terbanyak di Kalimantan Barat (DISKES, 2017)

Penderita DM sebagian besar memiliki gangguan saraf (neuropati) dan pembuluh darah (pernyakit pembuluh darah arteri) yang dapat mengakibatkan terjadinya perlukaan terutama pada kaki (Boulton et al., 2014). Luka kaki diabetik (LKD) adalah luka terbuka pada permukaan kulit yang dapat disertai adanya kematian jaringan setempat (Sussman \& Jensen, 2012).

Luka kaki pada penderita Diabetik dikaitkan dengan neuropati, penyakit pembuluh darah perifer atau keduanya (luka neuroiskemik). Luka neuropati biasanya terjadi karena adanya kelainan bentuk kaki, tekanan yang tinggi pada kaki, berkurangnya bantalan lemak pada kaki, trauma yang tidak diketahui penyebabnya (Ndip et al., 2012).

Gangguan sensorik disadari saat pasien mengeluhkan kaki kehilangan sensasi atau merasa kebas. Rasa kebas menyebabkan trauma yang terjadi pada pasien penyakit DM sering kali tidak diketahui (Muhartono \& Sari, 2017). Kemudian penurunan sensasi sensori dapat menyebabkan pasien DM berpeluang mengalami luka pada daerah kaki. Pasien DM dengan neuropati meningkatkan risiko terjadinya luka diabetikum tujuh kali lebih tinggi dibanding dengan pasien penyakit DM tidak neuropati.

Gangguan pada saraf tepi terutama pada saraf motorik mengakibatkan pengencilan otot sehingga otot kaki menjadi tidak seimbang dan mengakibatkan perubahan bentuk (deformitas) pada kaki seperti menekuk (cock up toes), bergesernya sendi (luksasi) pada sendi kaki depan dan terjadi penipisan bantalan lemak dibawah pangkal jari kaki sehingga terjadi perluasan daerah yang mengalami penekanan dan menimbulkan kalus atau kapalan (Purwanti dan Maghfirah 2016). Kalus adalah penebalan kulit dan pengerasan pada bantalan telapak kaki atau sisi luar ibu jari kaki akibat gesekan dan tekanan yang lama. Pada penderita diabetik melitus yang mengalami luka pada kaki menjadi sulit sembuh akibat tekanan beban tubuh dan penderita yang berjalan dengan masih menjadikan tumpuan berjalan pada kaki yang mengalami luka, maupun iritasi kronis dari alas kaki yang digunakan.

Luka kaki pada diabetik dikaitkan dengan neuropati, penyakit pembuluh darah perifer atau keduanya (luka neuroiskemik). Luka kaki diabetik neuropati biasanya terjadi karena adanya kelainan bentuk kaki, tekanan yang tinggi pada kaki, berkurangnya bantalan lemak pada kaki, trauma yang tidak diketahui penyebabnya (Ndip et al., 2012). Tekanan plantar yang tinggi berkontribusi terhadap kejadian luka. Selain itu, adanya beberapa kombinasi antara neuropati, kelainan bentuk kaki serta trauma memberikan kontribusi besar dalam perlukaan pasien dengan diabetes (Boulton et al., 2014)

Terdapat beberapa prinsip dalam perawatan luka pasien dengan masalah neuropati, salah satunya yaitu dengan offloading terutama pada kaki yang memiliki resiko tinggi tertekan karena adanya kelainan bentuk kaki (Bus et al., 2020). Off- 
loading adalah sebuah teknik yang digunakan untuk mengurangi tekanan pada plantar kaki atau daerah yang mengalami luka dengan mentransfer beban kedaerah lainnya. Tidak adekuatnya Off-loading terbukti akan menghambat dalam penyembuhan luka kaki diabetik neuropati. Terdapat empat kelompok metode offloading yang umum digunakan diseluruh dunia dalam praktek klinis yaitu teknik casting, penggunaan sepatu khusus, teknik off-loading bedah, teknik off-loading alternatif (Singh, 2017). Off-loading di Indonesia masih jarang dipakai, selain harganya yang mahal dan juga sulit untuk didapatkan. Untuk mengatasi permasalahan tersebut dapat digunakan jenis off-loading alternatif yaitu menggunakan alat sederhana dalam menghilangkan atau mengurangi beban tekanan.

Penggunaan off-loading sederhana ini dalam bentuk foam atau busa yang dialaskan kebagian plantar atau sekeliling luka sehingga luka akan terhindar dari tekanan yang berlebihan. Rata-rata ketebalan busa yang digunakan adalah 1,5$2 \mathrm{~cm}$. Penggunaan Off-loading secara berkelanjutan diharapkan mampu mempecepat penyembuhan pada luka neuropati diabetik.

Penelitian ini bertujuan untuk mengetahui dan mengevaluasi penggunaan off-loading sederhana terhadap perkembangan luka kaki diabetik neuropati. Pasien didapatkan dari pasien yang berkunjung di Klinik Kitamura. Luka yang diambil adalah jenis luka kaki diabetik neuropati.

\section{METODE PENELITIAN}

Jenis penelitian yang akan dilakukan merupakan penelitian eksperimen, dengan desain quasi eksperimen tanpa kontrol. Jumlah total sampel 16 namun 7 sampel tidak dilanjutkan intervensi dikarenakan tidak melakukan kunjungan kembali dan mengalami infeksi berulang. pasien dengan luka kaki diabetik neuropati. Perawatan menggunakan standar perawatan luka Klinik Kitamura yang ditambah dengan Off-loading sederhana. Penggunaan Off-loading sederhana ini dalam bentuk foam/busa yang dialaskan kebagian plantar atau sekeliling luka. Ketebalan foam/busa yang digunakan adalah 1,5-2 cm. Luka dievaluasi sebelum dan setelah perawatan selama 4 minggu yang meliputi skor luka (MUNGs) dan ukuran luka. MUNGs terdiri atas Maceration, Undermining, necrotic, Granulation dan Others Sign. Rentang skor 0-15, semakin tinggi skor luka maka kondisi luka menjadi tidak baik (Jais et al., 2016). Penelitian dilaksanakan dari 1 Juli sampai dengan 30 Oktober 2019.

Penelitian ini telah mendapatkan ijin dari komisi etik Fakultas Kedokteran Universitas Tanjungpura dengan nomor 6250/UN22.9/TA.00.03/2019. Perawatan luka dilakukan sesuai dengan standar perawatan luka yang dilaksanakan di Klinik Kitamura yang terdiri atas pencucian luka, debridemen dan aplikasi balutan. Offloading sederhana diberikan setelah selesai dilakukan perawatan luka. Evaluasi dilakukan setelah 4 minggu perawatan atau luka sembuh.

\section{HASIL DAN PEMBAHASAN}

\section{Tabel 1. Distribusi karakteristik}

\begin{tabular}{llll}
\hline Variabel & Katagori & $\mathrm{n}$ & $\%$ \\
\hline Jenis kelamin & Laki-laki & 1 & 11.1 \\
& Perempuan & 8 & 88.9 \\
Riwayat & Ya & 1 & 11.1 \\
Merokok & & 88. & 88.9 \\
& Tidak & 9 & \\
Monofilim & Normal & 4 & 44.4 \\
en & Tidak & 5 & 55.6 \\
& normal & & \\
\hline
\end{tabular}

Tabel 1 menunjukkan jenis kelamin terbesar ialah perempuan (88.9\%), sebagian besar tidak merokok (88.9\%) dan monofilament sebagian besar tidak normal (55.6\%). 
Tabel 2. Distribusi karakteristik rata-rata usia, GDS dan nilai ABI

\begin{tabular}{|c|c|c|c|}
\hline $\begin{array}{c}\text { Variab } \\
\text { el }\end{array}$ & $\begin{array}{c}\text { Rata- } \\
\text { rata } \pm S D\end{array}$ & $\begin{array}{c}\text { Media } \\
\mathrm{n}\end{array}$ & Min-Max \\
\hline Usia & $53.56 \pm 4.447$ & 54 & $45-60$ \\
\hline GDS & $\begin{array}{c}255.11 \pm 90.6 \\
26\end{array}$ & 254 & $119-400$ \\
\hline$A B I$ & $0.95 \pm 0.0934$ & 0.95 & $0.83-1.13$ \\
\hline
\end{tabular}

Table 2 menunjukkan hasil bahwa rata-rata usia yaitu 53.56 tahun, rata-rata nilai gula darah sewaktu $255.11 \mathrm{mg} / \mathrm{dl}$ dan rata-rata nilai ankle brachial indeks 0.95 .

Tabel 3. Nilai skor luka sebelum dan setelah intervensi

\begin{tabular}{|c|c|c|c|c|}
\hline & Variabel & $\mathrm{n}$ & Mean $\pm S D$ & $\mathrm{p}$ \\
\hline & Sebelum & & $3.22 \pm 1.093$ & \\
\hline $\begin{array}{l}\text { Skor } \\
\text { Luka }\end{array}$ & Setelah & 9 & $1.46 \pm 1.333$ & 0.05 \\
\hline
\end{tabular}

Table 3 menunjukkan hasil rata-rata skor luka sebelum 3.22 dengan standar deviasi 1.093 dan skor luka setelah intervensi 1.46 dengan standar deviasi 1.333. Nilai $p=0.05$.

Tabel 4. Nilai skor luka sebelum dan setelah intervensi

\begin{tabular}{|c|c|c|c|c|c|}
\hline \multicolumn{2}{|c|}{ Variabel } & $n$ & \multirow{2}{*}{$\begin{array}{c}\text { Median } \\
0.56\end{array}$} & \multirow{2}{*}{$\begin{array}{l}\text { Min- } \\
\text { Max } \\
0.32-\end{array}$} & \multirow{2}{*}{$p$} \\
\hline & Sebe & & & & \\
\hline $\begin{array}{l}\text { Ukuran } \\
\text { Luka }\end{array}$ & $\begin{array}{l}\text { Setel } \\
\text { ah }\end{array}$ & 9 & 0.30 & $\begin{array}{l}2.00 \\
0.00 \\
3.75\end{array}$ & 0.11 \\
\hline
\end{tabular}

Table 4 menunjukkan hasil median ukuran luka sebelum yaitu 0.56 dengan nilai minimum dan maksimum 0.32 dan 2.80. dan median ukuran luka setelah yaitu 0.30 dengan nilai minimum dan maksimum 0.00 dan 3.75. Nilai $p=0.11$. Berdasarkan pada penelitian ini terjadi percepatan penyembuhan luka kaki diabetik neuropati yang dievaluasi menggunakan MUNGs (Jais et al., 2016).

Pendekatan dalam perawatan luka dilihat berdasarkan pada dasar luka, tepi luka dan tepi luka (Dowsett et al., 2015). Selain itu perawatan luka harus memperhatikan tipe jaringan luka yang terdiri atas jaringan nekrotik, slough dan epitel. Pada bagian tepi luka yang harus diperhatikan adalah maserasi. Perawatan luka proses perawatan luka terdiri atas pencucian, debridement atau pengangkatan jaringan mati dan aplikasi dressing (Dowsett et al., 2015; Mohamed \& Al Lenjawi, 2016).

Menghilangkan atau mengurangi tekanan beban (off-loading) merupakan salah satu hal yang sangat penting namun sampai saat ini kurang mendapatkan perhatian dalam perawatan kaki diabetik. Tidak adekuatnya Off-loading terbukti akan menghambat dalam penyembuhan luka. Pada penderita diabetik melitus yang mengalami luka pada kaki menjadi sulit sembuh akibat tekanan beban tubuh dan penderita yang berjalan dengan masih menjadikan tumpuan berjalan pada kaki yang mengalami luka, maupun iritasi kronis dari alas kaki yang digunakan.

Off-loading adalah sebuah teknik yang digunakan untuk mengurangi tekanan pada plantar kaki atau daerah yang mengalami ulserasi dengan mentransfer beban kedaerah lainnya. off-loading merupakan salah satu intervensi yang berfungsi untuk mengurangi tekanan pada bagian yang beresiko untuk terjadinya luka dan mempercepat penyembuhan luka kaki diabetik neuropati. Tekanan yang berlebihan pada area luka akan mengakibatkan terhambatnya proses penyembuhan luka sehingga luka sulit untuk sembuh. Terdapat empat kelompok metode off-loading yang umum digunakan diseluruh dunia dalam praktek klinis yaitu: teknik casting, penggunaan sepatu khusus, teknik offloading bedah, teknik off-loading alternatif (Singh, 2017).

Salah satu metode menghilangkan beban pada kaki atau off-loading dapat dilakukan dengan teknik off-loading alternatif yaitu menggunakan alat sederhana Penggunaan Off-loading sederhana ini dalam bentuk foam/busa yang dialaskan kebagian plantar atau sekeliling luka mampu memfasilitasi percepatan penyembuhan atau penutupan luka. Penggunaan offloading sederhana ini dalam bentuk foam/busa yang dialaskan kebagian plantar 
atau sekeliling luka sehingga luka akan terhindar dari tekanan yang berlebihan. Tekanan pada luka sangat menghambat dalam penyembuhan luka neuropati. Ratarata ketebalan busa yang digunakan adalah $1,5-2 \mathrm{~cm}$.

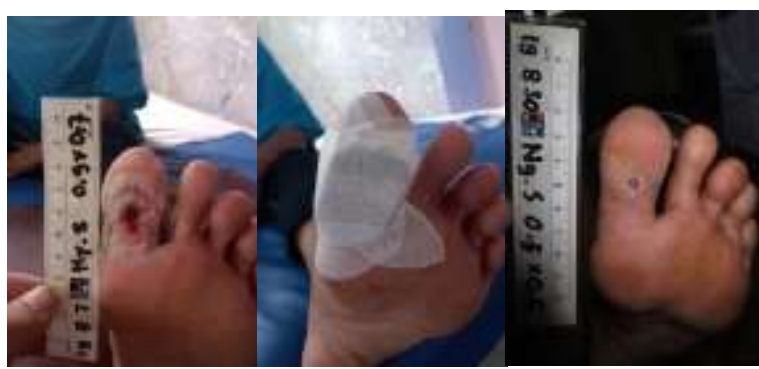

Gambar 1. Penggunaan foam sederhana

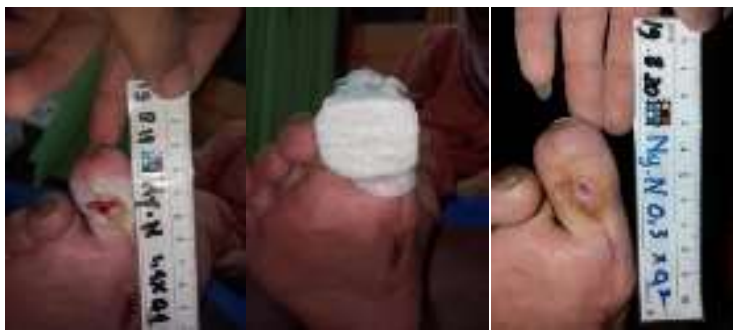

Gambar 2. Proses penyembuhan luka

Pada gambar 1 dan 2 merupakan gambaran klinik yang menunjukkan bahwa penggunaan off-loading sederhana sangat membantu percepatan penyembuhan luka kaki diabetic neuropati.

Hasil penelitian menyatakan bahwa penggunaan off-loading dalam bentuk tiga lapis mampu memberikan kesembuhan yang lebih cepat. Selain itu hasil Penelitian penggunaan off-loading sederhana yang dilakukan di india mampu mempercepat penyembuhan luka neuropati diabetik (Al Thebati et al., 2016; Shankhdhar et al., 2016)

Selain itu juga, penggunaan offloading sederhana mampu mengurangi pembentukan kalus yang sering muncul pada bagian tepi luka diakibatkan oleh tekanan. Kalus yang tebal merupakan penyebab luka menjadi lama sembuh dan dapat menyebabkan infeksi berulang. offloading mampu menjaga jaringan granulasi yang telah terbentuk tetap sehat dan mempercepat terbentuknya epiteliasasi.
Berdasarkan hasil penelitian untuk ukuran luka menunjukkan tidak ada perbedaan yang signifikan ukuran luka pada pasien dengan luka neuropati diabetik. Namun dari hasil penelitian didapatkan terjadi penurunan rata-rata ukuran luka hal ini dikarenakan luka neuropati memerlukan waktu yang lebih panjang untuk proses penyembuhannya dikarenakan dipengaruhi berbagai faktor. Memerlukan waktu yang lebih lama dalam pemberian off-loading untuk melihat proses luka sampai sembuh.

\section{KESIMPULAN}

Berdasarkan hasil Penelitian ini, penggunaan Off-loading sederhana memiliki pengaruh dalam mempercepat penyembuhan luka kaki diabetik neuropati sehingga dapat diaplikasikan difasilitas kesehatan.

\section{SARAN}

Perlu Penelitian lebih lanjut dengan pasien yang lebih banyak dan ditambah dengan kelompok kontrol sehingga hasilnya dapat dijadikan acuan dalam melakukan perawatan luka kaki diabetik neuropati.

\section{DAFTAR PUSTAKA}

Al Thebati, A. S., Al-Ouda, N. M., \& Al Khaldi, S. M. (2016). The Effectiveness of Three Layers Foam Dressing as an Offloading Technique in Treating Diabetic Foot Ulcer: Comparative Study. The Egyptian Journal of Hospital Medicine, 65(October), 648651.https://doi.org/10.12816/0033777

Boulton, A. J. M., Armstrong, D. G., Kirsner, R. S., Attinger, C. E., Authors, C., Andrew J.M. Boulton, Md, Dsc (Hon), Facp, F., Kirsner, R. S., Attinger, C. E., \& Lavery, L. A. (2014). Diabetic foot complications. U.S. Pharmacist, 39(6).

https://doi.org/10.5005/jp/books/1256 $\underline{024}$

Bus, S. A., Armstrong, D. G., Gooday, C., Jarl, G., Caravaggi, C., Viswanathan, V., \& Lazzarini, P. A. (2020). Guidelines on offloading foot ulcers in persons with diabetes (IWGDF 2019 update). Diabetes/Metabolism 
Research and Reviews,36(S1),1-18 https://doi.org/10.1002/dmrr.3274

DISKES. (2017). Profil Kesehatan 2017 Provisi Kalimantan Barat.

Dowsett, C., Drouard-Segard, M., Protz, K., \& Keith Harding. (2015). Triangle of Wound Assessment. May, 1-6.

Jais, S., Gusmiyah, T., Syafei, S., Kardiatun, T., Maktal, H., Jais, S., \& Fauzan, S. (2016). Clinical practice A reliability study of wound assessment tools for diabetic patients in Indonesia. Wounds International, 7(2), 5-9.

Mohamed, H., \& Al Lenjawi, B. (2016). Triangle of Wound Assessment Made Easy: Revisited. Dermatology - Open Journal, 1(3),51-55.

Muhartono, \& Sari, I. R. N. (2017). Ulkus Kaki Diabetik Kanan dengan Diabetes Mellitus Tipe 2 Diabetic. Unila Agromedicine Journal, 4(1), 133-139.

Ndip, A., Ebah, L., \& Mbako, A. (2012). Neuropathic diabetic foot ulcers evidence-to-practice. International Journal of General Medicine, 5, 129134.

https://doi.org/10.2147/IJGM.S10328

Purwanti, L. E., \& Maghfirah, S. (2016). Faktor Risiko Komplikasi Kronis (Kaki Diabetik) Dalam Diabetes Mellitus Tipe 2. The Indonesian Journal of Health Science, 7(1), 26-39.

Riskesdas. (2018). Riset Kesehatan Dasar 2018. In Kementrian Kesehatan Republik Indonesia. https://doi.org/1 Desember 2013

Shankhdhar, L., Shankhdhar, K., Shankhdhar, U., \& Shankhdhar, S. (2016). Instant Offloading of a Diabetic Foot Ulcer. Clinical Research on Foot \& Ankle, 4(3).

Shaw, J. E., Sicree, R. A., \& Zimmet, P. Z. (2010). Global estimates of the prevalence of diabetes for 2010 and 2030. Diabetes Research and Clinical Practice, 87(1), 4-14.
Singh, Simerjit. (2017). Offloading Techniques for Diabetic Foot. Journal of Diabetes, Metabolic Disorders \& Control, 4(3), 84-88. https://doi.org/10.15406/jdmdc.2017. $\underline{04.00112}$

Sussman, C., \& Jensen, B. (2012). Wound Care; A Collaborative Practice Manual for Health Professionals (4th ed.). Lippincott Williams \& Wilkins, a Wolters Kluwer business. 